American Journal of Biochemistry and Biotechnology 1 (4): 193-198, 2005

ISSN 1553-3468

(c) 2005 Science Publications

\title{
Multiple Antibiotic Resistances of Vibrio Isolates from Coastal and Brackish Water Areas
}

\author{
Manjusha S., Sarita G.B., Elyas K.K and Chandrasekaran M \\ Department of Biotechnology, Cochin University of Science and Technology, Cochin-682022, India
}

\begin{abstract}
An experiment was designed to assess the occurrence of multiple antibiotic resistances in Vibrio spp. from different (brackish and marine) environments. Water samples from nine marine landing sites and two coastal inland aquaculture farms were screened for the Vibrio spp. and assessed their resistance to twenty-two different antibiotics, which are commonly encountered in the aquatic ecosystem. Tissue samples (shrimp, mussel and sepia) were tested from the sampling site with highest antibiotic resistance. Of the total 119 Vibrio isolates, $16.8 \%$ were susceptible to all antibiotics. Of the resistant (83.19\%) Vibrio strains, 30.3\% were resistant against three antibiotics, 55.5\% were resistant against $4-10$ antibiotics, $14.14 \%$ were resistant against more than 10 antibiotics and $54 \%$ have shown multiple antibiotics resistance (MAR). Antibiotic resistance index was higher in Coastal 3, 6, Aqua farm 2 in isolates from water samples and all the tissues tested. Interestingly, incidence of antibiotic resistance in isolates from water samples was comparatively lower in aquaculture farms than that observed in coastal areas. Highest incidence of antibiotic resistance was evident against Amoxycillin, Ampicillin, Carbencillin and Cefuroxime followed by Rifampicin and Streptomycin and lowest against Chloramphenicol, Tetracycline, Chlortetracycline, Furazolidone, Nalidixic acid, Gentamycin Sulphafurazole, Trimethoprim, Neomycin and Amikacin irrespective of the sampling sites. Results from various tissue samples collected from the sites of highest antibiotic resistance indicated that antibiotic resistance Vibrio spp. collected from fish and tissue samples were higher than that of water samples. Overall results indicated that persistent use of antibiotics against diseases in human beings and other life forms may pollute the aquatic system and their impact on developing antibiotic resistant Vibrio spp. may be a serious threat in addition to the use of antibiotics in aquaculture farms.
\end{abstract}

Key words: Multiple antibiotic resistance, Vibrio spp., water, shrimp, mussel, sepia

\section{INTRODUCTION}

In India, capture fisheries contribute equally to the fish/shellfish products as compared to aqua cultured organisms until 1990 's ${ }^{[1]}$. However, due to the declining catch from capture fisheries, shrimp farming were initiated to maximize profits. Problems of diseases often accompanied this intensification as environmental conditions deteriorated and brought the decline of the aquaculture industry. Pressure to ensure production led to reliance on antibiotics, which are administered to farmed shrimp primarily to prevent or treat bacterial diseases. The presence of antimicrobial agents at low concentration through leaching or continued usage may lead to the development of drug-resistant strains and multiple antibiotic resistance (MAR) in bacteria, which ultimately result in transfer of resistance to pathogenic bacteria and reduced efficacy of antibiotic treatment for human and animal diseases. In the field of aquaculture, both therapeutic and environmental problems have been addressed, as antimicrobial agents are released into the surrounding water during treatment of bacterial fish diseases $^{[2,3]}$.
Bacteria of the genus Vibrio spp. are commonly found in coastal and estuarine waters. Some Vibrio strains are pathogenic and can cause Vibriosis, a serious infectious disease in both wild and cultured fish and shellfish $^{[4]}$. In recent years, Vibriosis has become one of the most important bacterial diseases in maricultured organisms, affecting a large number of species of fish and shellfish ${ }^{[5,6]}$. Antibiotics and other chemotherapeutic agents commonly used in fish farms either as feed additives or immersion baths to achieve either prophylaxis or therapy may result in an increase of drug-resistant bacteria as well as R-plasmids ${ }^{[7,8]}$. Furthermore, many species of halophilic vibrios have become recognized as potential human pathogens causing serious gastroenteritis or severe wound infection upon exposure to contaminated seafood and/or seawater ${ }^{[9]}$. A few studies on antibiotic resistance in shrimps have shown that luminous strains of Vibrio harveyi and $V$. splendidus isolated from shrimp larvae are resistant to erythromycin, kanamycin, pencicillin G, and streptomycin ${ }^{[10]}$. V. harveyi strains isolated from diseased shrimp were resistant to ampicillin, chlorotetracycline, ceprofloxacin, erythtromycin, furazolidone, gentamycin, nalidixic acid, neomycin,

Corresponding Author: Manjusha S, Department of Biotechnology, Cochin University of Science and Technology, Cochin 682022, India Ph: +91484 2575320 
nitrofurantoin, nitrofurazole, novobiocin, ofloxacin, oxytetracycline, penicillin $\mathrm{G}$, polymyxin $\mathrm{B}$, rifampicin, streptomycin, sulphamethezole, and sulphafurazole ${ }^{[11]}$. It was reported that Vibrio spp. and Aeromonas spp. from fish and shrimp were resistant to streptomycin and sensitive to oxolinic acid ${ }^{[12]}$. However, there are no reports available on a comparison of antibacterial resistance in Vibrio sp with reference to their ecological niches in the coastal waters of Kerala. Thus it was considered important to evaluate the possibility that culture and capture environment might behave as a reservoir of antibiotic multiresistant bacteria, increasing the risk of their transfer into fish, shellfish and human pathogens. Therefore, the present study was undertaken to assess the multiple antibiotic resistance in Vibrio spp. from different (brackish and marine) environments of south west coast of India.

\section{MATERIALS AND METHODS}

Sampling site: Water samples were collected from two brackish water shrimp farms and nine coastal landing sites of Kerala $\left(8^{\circ} 18^{\prime} \mathrm{N} 74^{\circ} 52 \mathrm{E}\right.$ to $\left.12^{\circ} 48^{\prime} \mathrm{N} 72^{\circ} 22^{\prime} \mathrm{E}\right)$. Shrimp, sepia and mussel samples were collected from representative areas based on the high incidence of antibiotic resistance. Different sampling sites were labeled as per the location (Table 1).

Water samples: One milliliter of water sample was serially diluted in autoclaved normal saline, plated and processed for analysis.

Seafood samples: Five shrimps from the site of highest incidence of antibiotic resistance were processed individually. Whole tissue were separately taken aseptically from the shrimp and placed in individual sterile test tubes and homogenized in $3 \mathrm{ml}$ autoclaved normal saline using sterile glass rod. The samples were serially diluted in autoclaved seawater, plated, and processed for further microbiological analysis.

Bacterial isolation and storage: Bacteria containing water and tissue homogenate in autoclaved normal saline were serially diluted and used for isolates of Vibrios spread plate technique. Two media: Zobell's medium $^{[13]}$ and Thiosulfate Citrate Bile Sucrose Agar (TCBS) (Himedia Laboratories, Mumbai) were used for this purpose. Isolated bacterial colonies from the plates were further sub cultured in above media. Nutrient broth culture with $20 \%$ glycerol and $2 \%$ sodium chloride were prepared and stored at $-80^{\circ} \mathrm{C}$ as stock.

Identification of bacteria: Isolated pure cultures of bacteria were grown on nutrient agar plates and used for identification using conventional biochemical tests $^{[14,15]}$. One-day-old cultures on nutrient agar were used as inocula.
Gram stain reaction and cell morphology was observed and the isolates were identified based on the standard scheme available for environmental Vibrio $^{[16]}$.

Antibiotic sensitivity test: Bacterial isolates were tested for anti-microbial sensitivity using the disc diffusion method ${ }^{[17]}$. The results were interpreted based on the recommendations of National Committee for Clinical Laboratory Standards for antimicrobial susceptibility tests ${ }^{[18]}$. The turbidity of the bacterial suspension was then compared with a MacFarland's barium sulfate standard solution corresponding to 1.5 $=10 \mathrm{cfu} / \mathrm{mL}$. If any increase in turbidity is compared to the standard were adjusted with seawater. The standardized bacterial suspension was then swab inoculated on to Muller Hinton Agar. (Himedia laboratories, Mumbai) using sterile cotton swabs, which were then left to dry for $10 \mathrm{~min}$ before placing the antimicrobial sensitivity discs. Antibiotic impregnated discs $8 \mathrm{~mm}$ diameter was used for the test. Disks containing the following antibacterial agents were plated on the plate and incubated over night: Amoxycillin (Am, $10 \mu \mathrm{g}$ ), Ampicillin (A, $10 \mu \mathrm{g}$ ), Carbenicillin $(\mathrm{Cb}, 100 \mu \mathrm{g})$, Cefuroxime $(\mathrm{Cu}, 30 \mu \mathrm{g})$, Chloramphenicol (C-30 $\mu \mathrm{g})$, Ciprofloxacin (Cf-5 $\mu \mathrm{g}$ ), Chlortetracycline $(\mathrm{Ct}-30 \mu \mathrm{g})$, Cotrimaxazole (Co-25 $\mu \mathrm{g})$ Doxycyclinehydrochloride (Do-30 $\mu \mathrm{g}$ ), Furazolidone

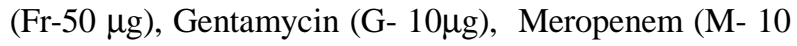
$\mu \mathrm{g})$, Netilmicin (N- $30 \mu \mathrm{g}$ ), Nalidixic acid (Na- $30 \mu \mathrm{g}$ ), Norfloxacin (Nx-10 $\mu \mathrm{g})$, Rifampicin (R-5 $\mu \mathrm{g})$. Streptomycin (S- $10 \mu \mathrm{g}$ ), Sulphafurazole (Sf-300 $\mu \mathrm{g}$ ), Trimethoprim (Tr-5 $\mu \mathrm{g})$, Tetracycline (T-30 $\mu \mathrm{g})$, Neomycin $(\mathrm{Ne}-5 \mu \mathrm{g})$, Amikacin (Ak-10 $\mu \mathrm{g})$. After incubation, the diameter of the zone of inhibition was measured and compared with zone diameter interpretative chart to determine the sensitivity of the isolates to the antibiotics. The procedure is intended for in vitro susceptibility testing of common rapidly growing and certain fastidious bacterial pathogens.

Antibiotic resistance index: Antibacterial resistance index (ARI) of each sampling site was determined using the formula ARI $=y / n x$, where $y$ was the actual number of resistance determinants recorded in a population of size $n$ and $x$ was the total number of antibacterial tested for in the sensitivity test. Based on the occurrence of resistance to more than three antibiotics the isolates of each sampling sites were also grouped as multiple antibiotic resistant isolates (Table 1).

Statististical analysis: Mean of antibiotic resistance pattern from different sampling sites were compared by one-way analysis of variance using statistical software (SPSS 10.0 for windows). Post hoc test was carried out using Duncan multiple range tests, if they were significant. 


\section{RESULTS}

Generic composition of Vibrio micro flora: A total of 456 isolates were examined for segregation of Vibrio spp. via preliminary screening: Gram staining, cytochrome oxidase test and marine oxidative fermentative tests. The bacterial isolate, which were Gram-negative rods/cocci, positive for oxidase test and oxidative fermentative, were segregated as Vibrios. One hundred and nineteen of the total isolates belonged to the genus Vibrio. Among Vibrio spp., V. anguillarum observed to be the predominant species in majority of the isolates from water and tissue samples.

Location wise comparison: Of the total 119 Vibrio isolates, $16.8 \%$ were susceptible to all antibiotics. Of the resistant (83.19\%) Vibrio strains, 30.3\% were resistant against three antibiotics (cluster I), 55.5\% were resistant against 4-10 antibiotics (cluster II), $14.14 \%$ were resistant against more than 10 antibiotics (cluster III) and 70.70\% exhibited Multiple Antibiotics Resistance (MAR).

The pattern of antibiotic resistance in Vibrios from different sources is represented as Table 1 and Fig. 1 and 2. In water samples, highest antibiotic resistance (>10 antibiotics) was evident in isolates from Coastal 3 followed by isolates from coastal $2(\mathrm{p}<0.05)$ (Fig. 1). Similarly, multiple antibiotic resistance index was highest in Coastal 3 and 5 isolates. Highest incidence of antibiotic resistance against three antibiotics (cluster I) was observed in Aquafarm 1 isolates. Antibiotic resistance against 4-10 antibiotics (cluster II) was observed in Coastal 1 isolates. Antibiotic resistance against antibiotics (>10) was highest in coastal 3 isolates (cluster III). Antibiotic resistance index was higher in Coastal 3, 6, Aqua farm 2 in isolates from water samples and all the tissues tested. Interestingly, incidence of antibiotic resistance in isolates from water samples was comparatively lower in aquaculture farms than that observed in coastal areas. Results of incidence of antibiotic resistance were in higher levels in all the three tissues over water samples from coastal and aqua farm samples (Table 1).

Antibiotic wise comparison: Percentage of antibiotic resistance is represented in Table 2. Highest incidence of antibiotic resistance was evident against Amoxycillin, Ampicillin, Carbencillin and Cefuroxime followed by Rifampin and Streptomycin irrespective of the sampling sites, of which higher antibiotic resistance were evident in tissue samples (mussel, shrimp, sepia) over water samples (Fig. 2). However, antibiotic resistance was lower against Chloramphenicol, Tetracycline, Chlortetracycline, Furazolidone, Nalidixicacid, Gentamycin Sulphafurazole, Trimethoprim, Neomycin and Amikacin (Table 2).

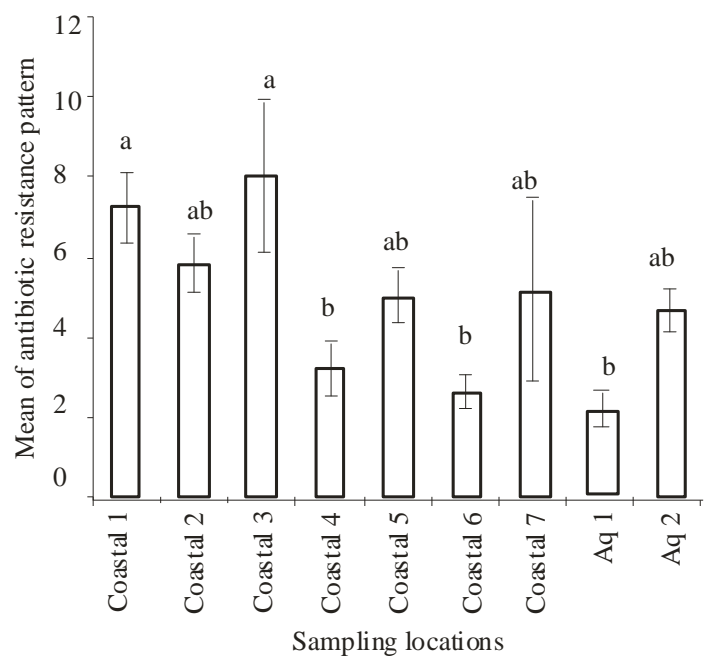

Fig. 1: Antibiotic resistance pattern in Vibrios from water samples from coastal landing stations and aquaculture farms. Different superscripts over different histograms indicate significant difference $(\mathrm{p}<0.05)$

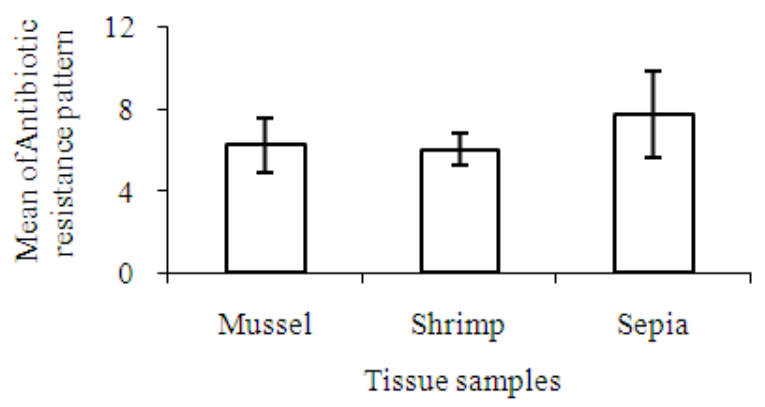

Fig. 2: Antibiotic resistance pattern in Vibrios from tissue samples of the coastal landing station with highest antibiotic resistance. Different tissue samples were not significantly different $(\mathrm{p}>0.05)$

\section{DISCUSSION}

The role of environment in the emergence and spread of antibiotic resistant bacteria and their possible pathways in which the environment bacteria contribute to the spread of resistance genes are not yet clear. The bacteria of our interest, Vibrio spp. occur widely in aquatic environments and are a part of normal flora of coastal seawaters. Therefore, we investigated the incidence of multiple antibiotic resistance in Vibrio spp. to different antibiotics commonly used in both aquaculture and other life forms including human beings.

Among different microflora, Vibrio spp. were identified in all the nine sampling sites tested. Of the different Vibrios, $V$. anguillarum was predominant in coastal environments. It is reported that $V$. anguillarum is often pathogenic in marine environments ${ }^{[19]}$. 
Am. J. Biochem. \& Biotech. 1 (4): 193-198, 2005

Table 1: Antibiotic resistance pattern in Vibrios from different sources

\begin{tabular}{|c|c|c|c|c|c|c|c|c|c|}
\hline \multirow[b]{2}{*}{ Sr. No. } & \multirow[b]{2}{*}{ Isolate } & \multirow{2}{*}{$\begin{array}{l}\text { Total Vibrio } \\
\text { isolates }\end{array}$} & \multirow[b]{2}{*}{ Susceptible } & \multicolumn{3}{|l|}{ Resistant } & \multirow{2}{*}{$\begin{array}{l}\text { Multiple } \\
\text { Antibiotic Resistant } \\
\text { isolates (MAR) }\end{array}$} & \multirow{2}{*}{$\begin{array}{l}\text { Antibiotic } \\
\text { resistance index }\end{array}$} & \\
\hline & & & & Cluster I & Cluster II & Cluster III & & & \\
\hline 1 & Coastal 1 & 12 & 2 & 1 & 7 & 2 & 9 & 0.04 & V. mimicus \\
\hline 2 & Coastal 2 & 13 & 2 & 2 & 9 & 0 & 9 & 0.04 & $\begin{array}{l}\text { V. proteolyticus } \\
\text { V. charchariaeae } \\
\text { V. metchnikowii } \\
\text { V. alginolyticus }\end{array}$ \\
\hline 3 & Coastal 3 & 10 & 0 & 2 & 5 & 3 & 8 & 0.05 & V. damsela \\
\hline 4 & Coastal 4 & 12 & 7 & 2 & 3 & 0 & 4 & 0.02 & V. anguillarum \\
\hline 5 & Coastal 5 & 10 & 2 & 2 & 6 & 0 & 6 & 0.04 & V. anguillarum \\
\hline 6 & Coastal 6 & 6 & 0 & 4 & 2 & 0 & 2 & 0.05 & $\begin{array}{l}\text { V. meditteranei } \\
\text { V. anguillarum } \\
\text { V. vulnificus } \\
\text { V. alginolyticus }\end{array}$ \\
\hline 7 & Coastal 7 & 10 & 5 & 3 & 1 & 1 & 2 & 0.02 & $V$. neries \\
\hline 8 & Aqua 1 & 8 & 2 & 6 & 0 & 0 & 0 & 0.03 & V. costicoloa \\
\hline 9 & Aqua 2 & 6 & 0 & 1 & 5 & 0 & 5 & 0.05 & V. anguillarum \\
\hline 10 & $\begin{array}{l}\text { Coastal 3- } \\
\text { Mussel }\end{array}$ & 12 & 0 & 5 & 3 & 4 & 7 & 0.05 & $\begin{array}{l}\text { V. marinus } \\
V . \text { anguillarum } \\
\text { V. charchariaeae } \\
\text { V. mimicus } \\
\text { V. alginolyticus }\end{array}$ \\
\hline 11 & $\begin{array}{l}\text { Coastal 3- } \\
\text { shrimp }\end{array}$ & 16 & 0 & 2 & 11 & 3 & 14 & 0.05 & $\begin{array}{l}V . \text { cincinnatiensis } \\
V . \text { pelagius } \\
\text { V. costicola }\end{array}$ \\
\hline 12 & $\begin{array}{l}\text { Coastal 3- } \\
\text { sepia }\end{array}$ & 4 & 0 & 0 & 3 & 1 & 4 & 0.05 & V. meditteranei \\
\hline
\end{tabular}

Cluster I: Contains isolates resistant to $\leq 3$ antibiotics, Cluster II: Contains isolates resistant to 4-10 antibiotics, Cluster III: Contains isolates resistant to $\geq 10$ antibiotics, MAR Group: Contains isolates resistant to more than three antibiotics

Table 2: Antibiotic resistance profile (individual antibiotic wise) from different sampling sites (\%)

\begin{tabular}{|c|c|c|c|c|c|c|c|c|c|c|c|c|}
\hline & $\begin{array}{l}\text { Coastal } 1 \\
n=12\end{array}$ & $\begin{array}{l}\text { Coastal } \\
n=13\end{array}$ & $\begin{array}{l}\text { Coastal } 3 \\
n=10\end{array}$ & $\begin{array}{l}\text { Coastal } 4 \\
n=12\end{array}$ & $\begin{array}{l}\text { Coastal } 5 \\
\mathrm{n}=10\end{array}$ & $\begin{array}{l}\text { Coastal } 6 \\
n=6\end{array}$ & $\begin{array}{l}\text { Coastal } \\
710\end{array}$ & $\begin{array}{l}\text { Aqual } \\
\mathrm{n}=8\end{array}$ & $\begin{array}{l}\text { Aqua } 2 \\
\mathrm{n}=6\end{array}$ & $\begin{array}{l}\text { Coastal 3- } \\
\text { Mussel } n=12\end{array}$ & $\begin{array}{l}\text { Coastal 3- } \\
\text { shrimp n = } 16\end{array}$ & $\begin{array}{l}\text { Coastal 3- } \\
\text { sepia } n=4\end{array}$ \\
\hline $\operatorname{MAR}(\%)$ & 90.00 & 81.80 & 80.00 & 80.00 & 75.00 & 33.00 & 40.00 & 0.00 & 83.30 & 58.33 & 87.50 & 100.00 \\
\hline Sensitive to all (\%) & 16.66 & 15.38 & 0.00 & 58.33 & 20.00 & 0.00 & 50.00 & 25.00 & 0.00 & 0.00 & 0.00 & 0.00 \\
\hline \multicolumn{13}{|l|}{ Resistant to (\%) } \\
\hline Amoxycillin & 75.00 & 84.62 & 90.00 & 33.33 & 80.00 & 100.00 & 50.00 & 50.00 & 66.67 & 100.00 & 100.00 & 100.00 \\
\hline Ampicillin & 75.00 & 84.62 & 90.00 & 33.33 & 80.00 & 100.00 & 50.00 & 37.50 & 83.33 & 100.00 & 100.00 & 100.00 \\
\hline Carbencillin & 50.00 & 38.46 & 80.00 & 16.67 & 60.00 & 16.67 & 30.00 & 0.00 & 16.67 & 66.67 & 100.00 & 100.00 \\
\hline Cefuroxime & 33.33 & 38.46 & 80.00 & 0.00 & 60.00 & 16.67 & 10.00 & 37.50 & 50.00 & 25.00 & 81.25 & 100.00 \\
\hline Chloramphenicol & 0.00 & 7.69 & 10.00 & 0.00 & 0.00 & 0.00 & 10.00 & 0.00 & 100.00 & 0.00 & 0.00 & 0.00 \\
\hline Ciprofloxacin & 00.00 & 0.00 & 10.00 & 0.00 & 0.00 & 0.00 & 0.00 & 0.00 & 0.00 & 16.67 & 6.25 & 0.00 \\
\hline Chlortetracycline & 0.00 & 7.69 & 0.00 & 0.00 & 0.00 & 0.00 & 0.00 & 0.00 & 0.00 & 0.00 & 0.00 & 0.00 \\
\hline Cotrimaxazole & 0.00 & 0.00 & 0.00 & 0.00 & 0.00 & 0.00 & 0.00 & 0.00 & 0.00 & 0.00 & 0.00 & 0.00 \\
\hline \multicolumn{13}{|l|}{ Doxycycline } \\
\hline hydrochloride & 0.00 & 53.85 & 10.00 & 0.00 & 0.00 & 0.00 & 0.00 & 0.00 & 0.00 & 16.67 & 6.25 & 0.00 \\
\hline Furazolidone & 16.66 & 7.69 & 20.00 & 0.00 & 0.00 & 0.00 & 0.00 & 0.00 & 0.00 & 25.00 & 0.00 & 0.00 \\
\hline Gentamycin & 41.66 & 0.00 & 10.00 & 0.00 & 10.00 & 0.00 & 0.00 & 12.50 & 0.00 & 8.33 & 6.25 & 0.00 \\
\hline Meropenem & 58.33 & 7.69 & 30.00 & 8.33 & 0.00 & 0.00 & 10.00 & 12.50 & 100.00 & 33.33 & 43.75 & 0.00 \\
\hline Netilmicin & 16.66 & 0.00 & 40.00 & 0.00 & 10.00 & 0.00 & 0.00 & 0.00 & 16.67 & 25.00 & 31.25 & 0.00 \\
\hline Nalidixicacid & 0.00 & 7.69 & 20.00 & 16.67 & 0.00 & 0.00 & 10.00 & 0.00 & 16.67 & 8.33 & 12.50 & 0.00 \\
\hline Norfloxacin & 0.00 & 7.69 & 10.00 & 0.00 & 0.00 & 0.00 & 0.00 & 0.00 & 0.00 & 8.33 & 12.50 & 0.00 \\
\hline Rifampicin & 75.00 & 38.46 & 50.00 & 16.67 & 50.00 & 0.00 & 10.00 & 0.00 & 33.33 & 41.67 & 56.25 & 25.00 \\
\hline Streptomycin & 83.33 & 53.85 & 40.00 & 8.33 & 50.00 & 16.67 & 20.00 & 0.00 & 50.00 & 50.00 & 37.50 & 25.00 \\
\hline Sulphafurazole & 0.00 & 0.00 & 20.00 & 0.00 & 0.00 & 0.00 & 10.00 & 0.00 & 0.00 & 25.00 & 0.00 & 25.00 \\
\hline Trimethoprim & 16.66 & 7.69 & 30.00 & 0.00 & 0.00 & 0.00 & 10.00 & 12.50 & 0.00 & 8.33 & 12.50 & 25.00 \\
\hline Tetracycline & 0.00 & 0.00 & 30.00 & 0.00 & 0.00 & 0.00 & 10.00 & 0.00 & 0.00 & 0.00 & 31.25 & 0.00 \\
\hline Neomycin & 8.33 & 30.77 & 30.00 & 0.00 & 0.00 & 0.00 & 0.00 & 0.00 & 0.00 & 25.00 & 0.00 & 0.00 \\
\hline Amikacin & 25.00 & 53.85 & 50.00 & 0.00 & 0.00 & 0.00 & 0.00 & 0.00 & 33.33 & 33.33 & 31.25 & 75.00 \\
\hline
\end{tabular}

Of the total Vibrio isolates from nine different locations, 16. $8 \%$ were susceptible to all antibiotics, $30.3 \%$ were resistant against three antibiotics, $55.5 \%$ were resistant against 4-10 antibiotics, and $14.14 \%$ were resistant against more than 10 antibiotics. This result indicate that majority of Vibrio spp. in aquatic environment develop resistance against antibiotics in coastal areas. Acquired antibiotic resistance in bacteria is generally mediated by extra chromosomal plasmids and is transmitted to next generation (vertical gene transfer) and also exchanged among different bacterial population (horizontal gene flow). Similar antibacterial multi resistance pattern was evident from some of the previous studies in Vibrio spp. from clinical samples ${ }^{[11]}$ shrimp ponds ${ }^{[20]}$ water and shrimp tissue samples ${ }^{[12]}$. Of the different sampling sites, coastal 3 samples appeared to have highest antibiotic resistance index among water samples. It was evident from our field survey that Coastal 3 sampling site is a disease prone area, where recurrent cholera outbreak were encountered. Persistent use of antibiotics against this disease outbreak might have resulted in acquired antibiotic resistance. Our results from various tissue samples collected from site of highest antibiotic resistance emphasizes the fact that 
antibiotic resistance in fish and tissue samples augment at alarming levels as compared to water samples. However, the antibiotic resistance levels in brackish water aquafarms were comparatively lower than coastal landing sites. This may be due to the fact that terrestrial bacteria entering into seawater with antibiotic resistant plasmids may be responsible for the prevalence of the resistance in genes in the marine environment ${ }^{[21]}$. Our investigation raises debate whether impact of polluted environment to aquaculture or the acquired antibiotic resistance due to aqua farming to open water bodies is serious with respect to our sampling sites.

Our results on antibiotic resistance (individual antibiotic wise) indicated that highest antibiotic resistance was evident against Amoxycillin, Ampicillin, Carbencillin, Cefuroxime, Rifampicin and Streptomycin. These antibiotics are frequently used against different terrestrial organisms including human beings. However, there are few reports available on acquired antibiotic resistance against ampicillin (68\%), cefuroxime $(66.7 \%)$, amikacin $(55 \%)$, kanamycin $(58.8 \%)$ and trimethoprim $(76.7 \%)$ in Sparus sarba in China $^{[22]}$. It can be presumed that anthropogenic factors (hospital effluents) might have influenced in acquiring resistance in Vibrio spp. due to these antibiotics, as there are no reports available on the use of these drugs for aquaculture in India. Interestingly, antibiotic resistance was lower against Chloramphenicol, Tetracycline, Chlortetracycline, Furazolidone, Nalidixicacid, Gentamycin Sulphafurazole, Trimethoprim, Neomycin and Amikacin, which are commonly used in aquaculture farms through feeds during culture and hatchery production of seeds. There similar reports available on the susceptibility of chloramphenicol and tetracycline in Sparus sarba in China $^{[22]}$. In addition, Aquaculture Authority of India banned 19 antibiotics including chloramphenicol, furazolidone, Nalidixicacid for the use in aquaculture farms ${ }^{[23]}$. Thus, these regulations might have restricted the use of these antibiotics in aquaculture.

To our knowledge, there is no report available on the multiple antibiotic resistances in Vibrios from coastal waters of India. However, the results of our present study serve as a baseline data for future research on the extent of antibiotic resistance, which may be revealed through isolation of plasmids, their transformation efficiency and conjugation experiments. Results of incidence of multiple antibiotic resistance in Vibrios may improve our knowledge on drug resistant strains and its effect on future therapy of shrimp as well as human diseases. Therefore, unscrupulous use of antibiotics against diseases should be avoided and restrictions for the use of antibiotics may be implemented by a nationwide antibiotic policy for India.

\section{ACKNOWLEDGEMENT}

The first researcher sincerely thanks Cochin University of Science and Technology for providing the research fellowship during this research period.

\section{REFERENCES}

1. FAO., 2002. Fisheries statistics- Aquaculture production 2000. FAO yearbook, Food and Agriculture Organization, Rome.

2. Aoki, T., T. Kitao, S. Watanabe and S. Takeshita, 1984. Drug resistance and $\mathrm{R}$ plasmids in Vibrio anguillarum isolated in cultured ayu (Plecoglossus altivelis). Microbiol. Immunol., 28: 1-9.

3. Aoki, T., 1992. Present and Future Problems Concerning the Development of Resistance in Aquaculture. In: Chemotherapy in Aquaculture: From Theory to Reality, Michel, C.M. and Alderman, D.J. (Eds.). Office International des Epizootics, Paris, pp: 254-262.

4. Austin, B. and D.A. Austin, 1993. Bacterial Fish Pathogens. 2nd Edn., Ellis Horwood, Chichester, pp: 265-307.

5. Woo, N.Y.S., J.L.M. Ling and K.M. Lo, 1995. Pathogenic Vibrio spp in the sea bream, Sparus sarba. J. Sun Eatsen Univ. Supp., 3: 192-193.

6. Wu, H.B. and J.P. Pan, 1997. Studies on the pathogenic bacteria of the Vibriosis of Seriola dumerili in marine cage culture. J. Fish. China, 21: 171-174.

7. Son, R., G. Rusul, A.M. Sahilah, A. Zainuri, A.R. Raha and I. Salmah, 1997. Antibiotic resistance and plasmid profile of Aeromonas hydrophila isolates from cultured fish, Tilapia (Tilapia mossambica). Lett. Applied Microbiol., 24: 479-482.

8. Saitanu, K., A. Chongthaleong, M. Endo, T. Umeda, K. Takami, T. Aoki and T. Kitao, 1994. Antimicrobial susceptibilities and detection of transferable R-plasmids from Aeromonas hydrophila in Thailand. Asian Fish. Sci., 7: 41-46.

9. French, G.L., M.L. Woo, Y.W. Hui and K.Y. Chan, 1989 Antimicrobial susceptibilities of halophilic vibrios. J. Antimicrob. Chemother., 24: 183-194.

10. Baticados, M.C.L., C.R. Lavilla-Pitogo, E.R. CruzLacierda, L.D. de la Pena and N.A. Sunaz, 1990. Studies on the chemical control of luminous bacteria Vibrio harveyi and V. splendidus isolated from diseased Penaeus monodon larvae and rearing water. Dis. Aquat. Org., 9: 133-139.

11. Abraham, T.J., R. Manley, R. Palaniappan and K. Dhevendaran, 1997. Pathogenicity and antibiotic sensitivity of luminous Vibrio harveyi isolated from diseased penaeid shrimp. J. Aquat. Trop., 12: 1-8. 
12. Leano, E.M., V.B.M. Inglis and I.H. MacRae, 1999. Antibiotic resistance of Vibrio spp. and Aeromonas spp. isolated from fish and shrimp tissues and rearing water in Panay Island, Philippines. UPV J. Nat. Sci., 3-11.

13. Aaronson, S., 1970. Experimental Microbial Ecology. Academic Press, New York, pp: 236.

14. MacFadden, J.F., 1976. Biochemical Tests for the Identification of Medical Bacteria. Williams and Wilkens, Baltimore, pp: 310.

15. West, P.A. and R.R. Colwell, 1984. Identification of Vibrionaceae: An overview. In: Vibrios in the Environment, Colwell, R.R. (Ed.). Wiley, New York, USA., pp: 205-363.

16. Alsina, M. and A.R. Blanch, 1994. A set of keys for biochemical identification of environmental Vibrio species. J. Applied Bacteriol., 76: 79-85.

17. Bauer, A.W., M.M. Kirby, J.C. Sherris and M. Turch, 1966. Antibiotic susceptibility testing by standardized single disc method. Am. J. Clinical Path., 36: 493-496.

18. Finegold, S.M. and W.J. Martin, 1982. Bailey and Scott's Diagnostic Microbiology. C.V. Mosby, Philadelphia.
19. Larsen, J.L. and J.E. Olsen, 1991. Ocurrence of plasmids in Danish isolates of Vibrio anguillarum Serovars O1 O2 and association of plasmids with phenotypic characteristics. Applied Environ. Microbiol., 57: 2158-2163.

20. Eleonor, A. and D. Leobert, 2001. Antibiotic resistance of bacteria from shrimp ponds. Aquaculture, 195: 193-204.

21. Chandrasekaran, S., B. Venkatesh and D. Lalithakumari, 1998. Transfer and expression of a multiple antibiotic resistance plasmid in marine bacteria. Curr. Microbiol., 37: 347-351.

22. Li, J., J. Yie, W. Rita, T. Foo, M.L.L. Julia, H. Xu and N.Y.S. Woo, 1999 Antibiotic resistance and plasmid profiles of Vibrio isolates from cultured Sparus sarba. Mar. Poll. Bull., 39: 245-249.

23. Aquaculture News, 2003. List Antibiotics Banned in India. Marine Products Exports Authority of India, Cochin, pp: 2-3. 